\title{
Urokinase Plasminogen Activator Surface Receptor
}

National Cancer Institute

\section{Source}

National Cancer Institute. Urokinase Plasminogen Activator Surface Receptor. NCI

Thesaurus. Code C17321.

Urokinase plasminogen activator surface receptor (335 aa, $\sim 37 \mathrm{kDa}$ ) is encoded by the human PLAUR gene. This protein is involved in urokinase localization, plasmin formation, and signal transduction. 